\title{
Evaluation of the stance phases of warmblood sport horses on soft and hard surfaces by infrared optical sensors
}

\author{
Ozan Gündemir ${ }^{1}$, Dilek Olğun Erdikmen², and Çağla Parkan Yaramış* \\ ${ }^{1}$ Department of Anatomy, Faculty of Veterinary Medicine, Istanbul University-Cerrahpaşa, Istanbul, Turkey \\ ${ }^{2}$ Department of Surgery, Faculty of Veterinary Medicine, Istanbul University-Cerrahpaşa, Istanbul, Turkey \\ ${ }^{3}$ Equine and Equine Training Program, Vocational School of Veterinary Medicine, Istanbul University - Cerrahpaşa, \\ Istanbul, Turkey
}

GÜNDEMIR, O., D. OLĞUN ERDIKMEN, Ç. PARKAN YARAMIŞ: Evaluation of the stance phases of warmblood sport horses on soft and hard surfaces by infrared optical sensors. Vet. arhiv 91, 109-116, 2021.

\section{ABSTRACT}

The aim of the study was to assertain the differences in walking time of sport horses by investigating their stance phases on soft versus hard surfaces using infrared sensors. A total of 15 warmblood sport horses were used in the study. Three different stages of the stance phase were examined, including initial contact, foot flat and propulsion, alongside assessment of walking pace and step-length. It was observed that the horses were inclined to walk more slowly on soft surfaces compared to hard ground. The amount of time spent in the foot flat position constituted the majority of the stance phase on both surfaces. Propulsion length during the stance phase was shorter on soft surfaces in comparison to hard ground. While the ratio of contact length in forelimbs was lower on hard ground compared to soft surfaces, in hind limbs this ratio was higher on hard ground. Objective data obtained through gait analysis systems are thought to serve as a potential auxiliary diagnostic tool in diseases associated with the locomotor system manifested by lameness, particularly in equine veterinary medicine. In the future, the relevant systems that could offer rapid results through current technology are anticipated to provide accurate preliminary assumptions to evaluate the potential of horses regarding their walking, trotting, and leaping capacity before competitions through such studies.

Key words: gait analysis; infrared optic sensors; stance phase; walk; horse

\section{Introduction}

Lameness is one of the most common for subjective evaluation of mild lameness is complaints with which horses are referred to a only $50-60 \%$, and consequently poor agreement veterinarian (MOORMAN et al., 2017). Subjective evaluation of lameness is the commonly held standard for detecting clinical lameness, and includes visualization of local, regional and wholebody movements. However, the consistency ratio in subjective evaluations is still apt to prompt the development of objective methods to detect and quantify lameness, in both clinical trials and research designs (DONNELL et al., 2015; WEISHAUPT et al., 2004).

\footnotetext{
*Corresponding author:

Assoc. Prof. Çağla Parkan Yaramış, Equine and Equine Training Program, Vocational School of Veterinary Medicine, Istanbul UniversityCerrahpaşa, Istanbul, Turkey, Phone: +90 530645 74 84; E-mail: cparkan@istanbul.edu.tr
} 
Gait analysis is a systematic evaluation system to assess body movements, body mechanics, and muscle activity using miscellaneous equipment. Anatomic abnormalities and potential locomotor system-associated diseases may be detected by a variety of devices developed for this purpose. Devices initially used solely in human medicine have been reported to have been used in disorders of the nervous system such as Parkinson's disease, alongside gait abnormalities (PISTACCHI et al., 2017). Substantial reference information has been established regarding the relevant system that is currently also in use in veterinary medicine (MOORMAN et al., 2017). Perpendicular forces exerted by animal paws on the ground were measured in several studies conducted using the force plate system that is one of the most commonly applied methods (MCLAUGHLIN et al., 1996). The inertial sensory technique, used to assess analytic sensitivity, and the pressure analysis system to calculate the level of pressure exerted by each horse hoof on the ground in Newton units, which enables foot mapping, are listed among the gait analysis systems used in horses (GOMESCOSTA et al., 2015; DONNELL et al., 2015). Furthermore, reference information was collected through electronic chips used to investigate the effects of movements during the gait process on the musculoskeletalsystem(SWANSTROMetal.,2005).

A single step is comprised of the stance and swing phases (temporospatial gait parameters). The stance phase starts with the initial contact of the foot with the ground, and continues until the end of the last contact of the same foot. The stance phase comprises 3 sub-phases. The first stage is the "Contact Phase" (CP) that denotes the time spent between the first contact of the foot with the ground and the ground contact of the sole of the same food. "Foot Flat" (FF) is the second phase that indicates the period that the foot is entirely on the ground. The third and the last stage, the "Propulsive Phase" (PP), involves the time interval which starts with the lift of the foot off the ground and ends once the contact period with the ground has been thoroughly completed (CLAYTON et al., 1998).

OptoGait (FullBalance, İstanbul), applied in this study, is a system for optical detection that functions using one transmitting and one receiving bar. Each bar contains 96 Light Emitting Diodes (LED) that continuously communicate on an infrared (visible) frequency, with the same number of $L E D s$ on the opposite bar. Once positioned on the floor or the treadmill, the system senses interruptions in communication between the bars, caused by the patient's movements, and calculates the duration and the position. During the execution of a running gait or a series of jump tests, the contact and flight times can be estimated with an accuracy of one-thousandth of a second, and the position of the interrupted LEDs with a space resolution of $1.041 \mathrm{~cm}$. Starting from these basic data, the dedicated software measures a series of crucial data for movement analysis in real-time. The absence of mechanical moving parts in the device ensures longer life, improved accuracy and repetition possibilities (ENGELSON et al., 2017; HEALY et al., 2019; DUCA et al., 2017; LIENHARD et al., 2013; LEE et al., 2014a; LEE et al., 2014b). The system was first developed in the medical field to detect gait disorders in humans (ENGELSON et al., 2017; HEALY et al., 2019). In addition, an attempt was made to evaluate delayed motor development which results in impaired gait in patients with Down syndrome using the same system (DUCA et al., 2017).

The diagnosis of lameness in veterinary medicine is mostly based on the subjective observations of veterinarians. It is considered that the accuracy of the diagnosis will increase by using the objective data collected through these systems. Particularly in equine medicine, gait analysis systems similar to the system used in the present study will assist veterinarians in the diagnosis of gait disorder generating diseases and conditions such as lameness. It was assumed that the evaluation of the stance phases employing non-invasive methods, such as the use of infrared optical sensors, avoided uneasiness in the horses and thus contributed to the accuracy of the results. Likewise, high-tech devices capable of rapid gait analysis are considered to provide significant information regarding the potential walking, trotting and leaping skills of the horses before competitions. As in our ongoing studies (GÜNDEMİR et al., 2019), after the 
objective determination of the physiological values of the step lengths on different breeds and different grounds using the OptoGait analysis system, it will be revealed whether it is a clinically meaningful system in the diagnosis of lameness, alongside other future studies with healthy and lame horses.

The objective of the study was to investigate the stance phases of horses on soft and hard ground using infrared optical sensors, and to demonstrate the differences in walking pace and length between these two surfaces, since the ground reaction forces supported by the limbs exert greater magnitude in the stance phase.

\section{Materials and methods}

A total of 15 (4 mares and 11 geldings) warmblood jumping horses, between 9-15 years of age, weighing $550-650 \mathrm{~kg}$, were included in the study. All of them were shod horses with routinely treated hooves, and orthopedic examinations revealed no signs of lameness. The study was approved by the Local Ethics Committee of Istanbul University - Cerrahpaşa, Faculty of Veterinary Medicine (Approval number: 2019-92315)

OptoGait is a system performed for movement analysis and functional assessment of healthy or sick persons. The system contains one receiving and one transmitting bar, each of which has 96 interrelated infrared LED sensors communicating at a frequency of $1000 \mathrm{~Hz}$. The movements between these bars are perceived by these sensors and transferred to a computer. Coarse data for each step is processed by a software program (Software OptoGait v. 1.12.1.0) and read on the computer as one-thousandth of the contact period. The movements are also recorded by the cameras ensuring to which limb the data belongs.

The testing area consisted of two one-meterlong parallel bars that were initially placed on a hard surface and then on a soft surface (Fig. 1). A non-flexible concrete floor served as the hard surface, whereas high-density rubber matting with a thickness of $2 \mathrm{~cm}$ constituted the soft ground. This flexible rubber matting is used in the barn and its aisles, examination rooms, and hand-walking areas. The rubber matting, featuring suspension and high abrasion resistance, is also preferred in open areas. Horses were walked at least three times through the testing area to get used to the hard and soft surfaces, and also to the bars. For the accuracy of the results, the same experienced handler walked all of the horses on both surfaces and took the stance phase measurements. The horses passed through the platform 6 times for each floor. Four measurements per foot were evaluated. A total of 32 steps by each horse were taken for both surfaces. The steps relating to the ends of the platform were excluded from the total steps. The duration of the stance phases was recorded separately in milliseconds (ms). Sections of the stance phases were recorded separately;

Contact Phase (CP): The time interval that begins with the initial contact of the hoof tip and ends with the full contact of the sole of the same foot with the ground (Fig. 2A).

Foot Flat $(F F)$ : The entire period that the sole is on the ground (Fig. 2B).

Propulsive Phase (PP): The time interval that begins as the heel lifts off the ground and ends with the full lift of the same hoof (Fig. 2C).

Furthermore, the ratio of the stance phase proportion of each period was calculated as follows:

Stance Phase: CP time + FF time + PP time, for ms $961 \mathrm{~ms}(100 \%): 3 \mathrm{~ms}(0.3 \%)+906 \mathrm{~ms}(94.3 \%)+$ $52 \mathrm{~ms}(5.4 \%)$

Arithmetic means of the length of the stance phase on each surface were calculated. The SPSS program (SPSS for Windows, version 21.0) was used in the statistical analysis of the data obtained during the study. The Independent Samples Test was applied to test the differences between the groups;

$1^{\text {st }}$ group: Statistical evaluation of the stance phase values of the forelimb and hind limb steps.

$2^{\text {nd }}$ group: Statistical evaluation of the percentage of stance phases on hard and soft surfaces.

$3^{\text {rd }}$ group: Statistical evaluation of the percentage of stance phase of the forelimb and hind limb, regardless of floor difference. 

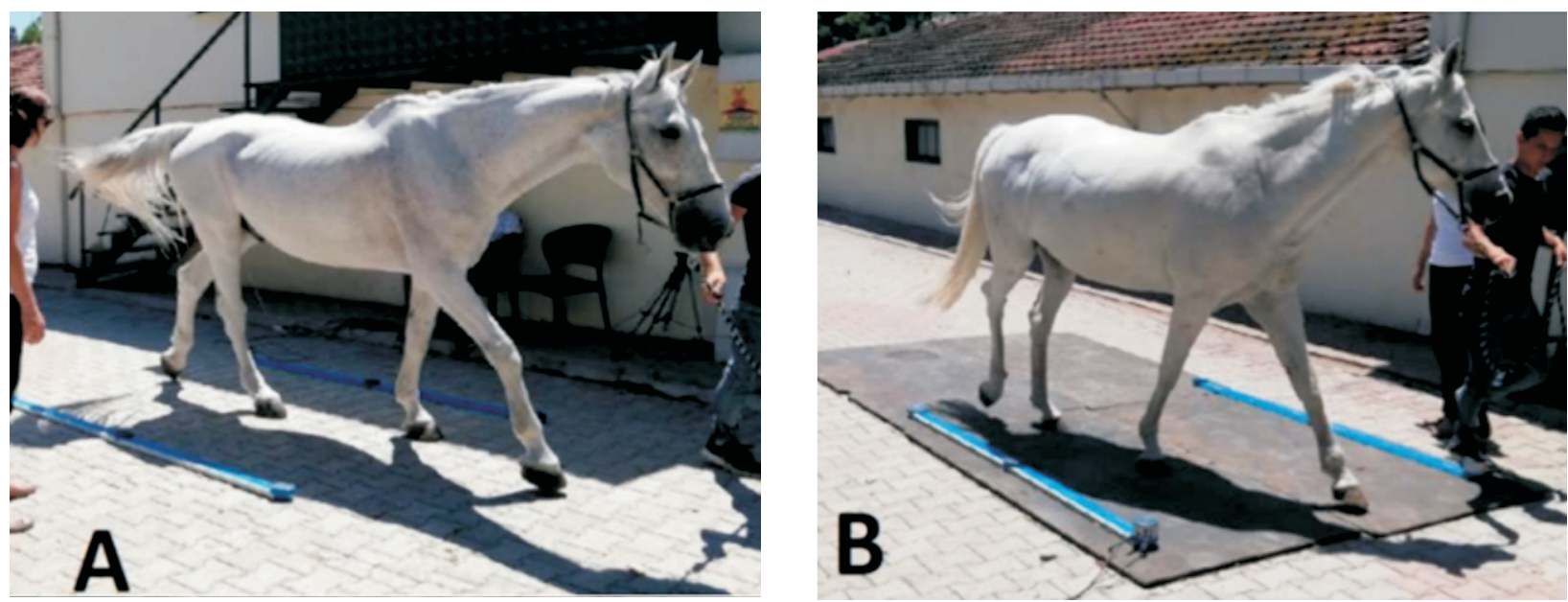

Fig. 1. Measuring walking phases A - Hard Surfaces, B - Soft surfaces in a horse by OptoGait analysis system

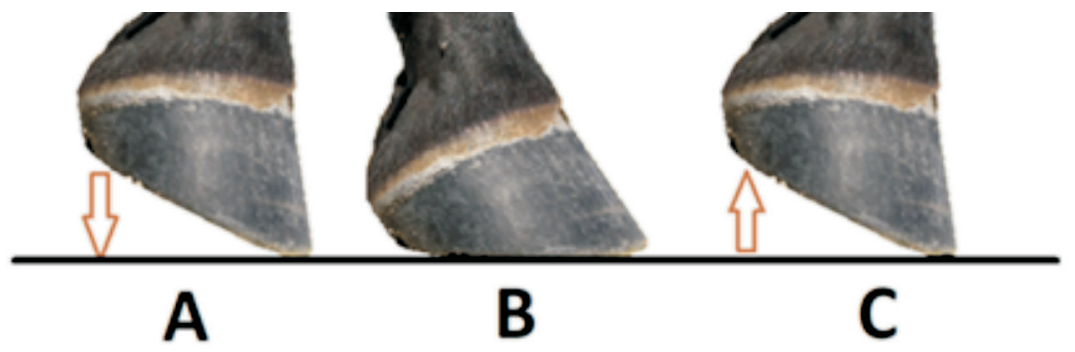

Fig. 2. Parts of the stance phase; A - Contact phase, B - Foot flat, C - Propulsive phase

\section{Results}

The mean walking pace of all 15 horses, walked by the same handler, was 1.59 seconds/meter $(\mathrm{s} / \mathrm{m})$ on the hard surface while on the soft surface it was recorded as $1.24 \mathrm{~s} / \mathrm{m}$. The step-lengths were $89.33 \mathrm{~cm}$ and $82.81 \mathrm{~cm}$ on the hard and the soft surface, respectively. The mean length of the stance phase period on the hard ground was $890 \mathrm{~ms}, 885$ $\mathrm{ms}, 923 \mathrm{~ms}$, and $917 \mathrm{~ms}$ for the right forelimb, the left forelimb, the right hind limb, and the left hind limb, respectively. The measurements of the same parameters on the soft ground were $990 \mathrm{~ms}, 959 \mathrm{~ms}$, $942 \mathrm{~ms}$, and $944 \mathrm{~ms}$, respectively. It was detected that the stance phase period was longer for each limb on the soft surface. The difference for forelimbs on hard versus the soft ground was statistically significant $(\mathrm{P}<0.01)$, whereas the measurements for hind limbs revealed no statistically significant difference. The means of the stance phase period and the standard deviation are shown in Table 1.
The mean length of $\mathrm{CP}, \mathrm{FF}$, and PP occupying the stance phase period on the hard ground was $1.89 \%, 86.7 \%$, and $11.4 \%$, respectively for the forelimbs. The same parameters of the forelimbs on the soft ground were measured as $2.41 \%, 91.35 \%$, and $6.23 \%$, respectively. The CP period of the stance phase was shorter on hard than on the soft ground for the forelimbs, which was a statistically significant difference $(\mathrm{P}<0.01)$. On the other hand, the mean length of CP, FF, and PP in the stance phase period on the hard ground was $1.87 \%, 83.81 \%$, and $14.1 \%$, respectively for the hind limbs, whereas the percentage values of the same parameters were $1.17 \%, 87.34 \%$, and $11.49 \%$, respectively, on the soft surface. The CP period of the hind limbs was also shorter on the soft ground, and the difference was statistically significant $(\mathrm{P}<0.05)$. From these findings it was seen that the length of the $\mathrm{CP}$ period was the determinative parameter on the hard or soft surface. 
The stages of the stance phase for each limb are shown in Table 2. The PP period of the stance phase was shorter on the soft ground for each limb than on the hard ground. The majority of the stance phase was occupied by the time interval spent in the foot flat position on both surfaces (Table 3).

On the basis of the findings assessed irrespective of the surface difference, we found that the CP period of the forelimbs accounted for $21.5 \%$ ( \pm
2.03 ) of the stance phase, but $1.52 \%( \pm 1.53)$ for the hind limbs. The FF periods of the forelimbs and hind limbs comprised $89.03 \%$ ( \pm 3.87 ) and $85.57 \%$ of the stance phase $( \pm 4.51)$, respectively, whereas the PP periods of those limbs comprised $8.81 \%$ ( $\pm 3.49)$ and $12.9 \%( \pm 4.12)$ of the stance phase, respectively. The measured values for the $\mathrm{CP}, \mathrm{FF}$ and PP periods for the forelimbs and hind limbs differed significantly $(\mathrm{P}<0.01)$ (Table 4$)$.

Table 1. Average and standard deviation of the stance phase values of the forelimb and hind limb steps

\begin{tabular}{|l|c|c|c|c|}
\hline & Surface & N (Step) & Mean (ms) & Standard Deviation (ms) \\
\hline \multirow{2}{*}{ Forelimb Stance Phase } & Hard & 120 & $888^{\mathrm{a}}$ & 79 \\
\cline { 2 - 5 } & Soft & 120 & $974^{\mathrm{b}}$ & 139 \\
\hline \multirow{2}{*}{ Hind limb Stance Phase } & Hard & 120 & $920^{\mathrm{a}}$ & 96 \\
\cline { 2 - 5 } & Soft & 120 & $943^{\mathrm{a}}$ & 100 \\
\hline
\end{tabular}

${ }_{\mathrm{a}, \mathrm{b}}$ different letters differ significantly $(\mathrm{P}<0.01)$

Table 2. Percentage distribution of the stance phases of the forelimb and hind limb

\begin{tabular}{|l|c|c|c|c|c|c|}
\hline & \multicolumn{3}{|c|}{ Hard surfaces } & \multicolumn{3}{c|}{ Soft surfaces } \\
\hline & $\begin{array}{c}\mathrm{N} \\
(\text { Step })\end{array}$ & $\begin{array}{c}\text { Mean } \\
(\%)\end{array}$ & $\begin{array}{c}\text { Standard Deviation } \\
(\%)\end{array}$ & $\begin{array}{c}\mathrm{N} \\
(\text { Step })\end{array}$ & $\begin{array}{c}\text { Mean } \\
(\%)\end{array}$ & $\begin{array}{c}\text { Standard Deviation } \\
(\%)\end{array}$ \\
\hline Forelimb Right CP & 120 & 1.82 & 1.12 & 120 & 2.25 & 2.35 \\
\hline Forelimb Right FF & 120 & 86.86 & 2.70 & 120 & 91.48 & 3.36 \\
\hline Forelimb Right PP & 120 & 11.32 & 2.34 & 120 & 6.27 & 2.16 \\
\hline Forelimb Left CP & 120 & 1.97 & 1.39 & 120 & 2.58 & 2.77 \\
\hline Forelimb Left FF & 120 & 86.55 & 3.11 & 120 & 91.23 & 3.24 \\
\hline Forelimb Left PP & 120 & 11.48 & 2.48 & 120 & 6.19 & 2.46 \\
\hline Hind limb Right CP & 120 & 2.14 & 1.62 & 120 & 1.21 & 1.14 \\
\hline Hind limb Right FF & 120 & 84.35 & 4.37 & 120 & 87.50 & 3.22 \\
\hline Hind limb Right PP & 120 & 13.51 & 4.05 & 120 & 11.30 & 2.96 \\
\hline Hind limb Left CP & 120 & 1.61 & 1.88 & 120 & 1.13 & 1.17 \\
\hline Hind limb Left FF & 120 & 83.27 & 4.24 & 120 & 87.19 & 4.69 \\
\hline Hind limb Left PP & 120 & 15.12 & 3.63 & 120 & 11.69 & 4.59 \\
\hline
\end{tabular}

CP - Contact Phase, FF - Foot Flat, PP - Propulsive Phase 
O. Gündemir et al.: Stance phases of horses on soft and hard surfaces

Table 3. Percentage of stance phases on hard and soft surfaces

\begin{tabular}{|c|c|c|c|c|c|c|c|c|}
\hline \multirow{2}{*}{} & & \multicolumn{3}{|c|}{ Hard surfaces } & \multicolumn{3}{c|}{ Soft surfaces } & \\
\cline { 2 - 10 } Phases & Limbs & N (Step) & Mean & $\begin{array}{c}\text { Standard } \\
\text { Deviation }\end{array}$ & N (Step) & Mean & $\begin{array}{c}\text { Standard } \\
\text { Deviation }\end{array}$ & P Value \\
\hline CP $(\%)$ & Forelimb & 120 & 1.895 & 1.2585 & 120 & 2.413 & 2.5608 & P $<0.05$ \\
\cline { 2 - 10 } & Hind limb & 120 & 1.874 & 1.7685 & 120 & 1.167 & 1.1505 & P $<0.05$ \\
\hline \multirow{2}{*}{ FF (\%) } & Forelimb & 120 & 86.706 & 2.9013 & 120 & 91.356 & 3.2889 & NS \\
\cline { 2 - 10 } & Hind limb & 120 & 83.812 & 4.3202 & 120 & 87.343 & 4.0069 & NS \\
\hline \multirow{2}{*}{ PP (\%) } & Forelimb & 120 & 11.399 & 2.3998 & 120 & 6.231 & 2.3054 & NS \\
\cline { 2 - 10 } & Hind limb & 120 & 14.314 & 3.9139 & 120 & 11.490 & 3.8519 & NS \\
\hline
\end{tabular}

CP - Contact Phase, FF - Foot Flat, PP - Propulsive Phase, NS - Non significantly

Table 4. Percentage of stance phase of forelimb and hind limb regardless of floor difference

\begin{tabular}{|c|c|c|c|c|c|c|c|}
\hline \multirow[b]{2}{*}{$\begin{array}{l}\text { Stance } \\
\text { Phases }\end{array}$} & \multicolumn{3}{|c|}{ Forelimb } & \multicolumn{3}{|c|}{ Hind limb } & \multirow[b]{2}{*}{ P Value } \\
\hline & $\mathrm{N}$ (Step) & Mean & $\begin{array}{l}\text { Standard } \\
\text { Deviation }\end{array}$ & $\mathrm{N}$ (Step) & Mean & $\begin{array}{l}\text { Standard } \\
\text { Deviation }\end{array}$ & \\
\hline $\mathrm{CP}(\%)$ & 240 & 2.154 & 2.0301 & 240 & 1.520 & 1.5303 & $\mathrm{P}<0.01$ \\
\hline FF $(\%)$ & 240 & 89.031 & 3.8737 & 240 & 85.578 & 4.5187 & $\mathrm{P}<0.01$ \\
\hline PP $(\%)$ & 240 & 8.815 & 3.4957 & 240 & 12.902 & 4.1252 & $\mathrm{P}<0.01$ \\
\hline
\end{tabular}

CP - Contact Phase, FF - Foot Flat, PP - Propulsive Phase, NS - Non significantly

\section{Discussion}

On the basis of the findings obtained in the study, it may be deduced that the duration of the stride of horses that were walked by the same handler at a constant speed on both surfaces was longer on the soft ground, and thus the stance phase period was longer on soft than on hard ground. Moreover, it was intriguing that the PP period was shorter on the soft than on the hard ground. The fact that the flexor tendons were actively mobilized in propulsion, enabling the flexion of the relevant extremities, at the end stage of the stance phase, was considered to be quantitative evidence of the physiological response exerted. Therefore, it may be concluded that horses move faster on hard surfaces (KORSGAARD et al., 1982).

Previously, the stance phases of horses were measured using infrared optical sensors. The mean values of the duration of the forelimb stance phase (CP, FF and PP) of animals measured on soil were reported as $2.36 \%, 89.06 \%$ and $9.45 \%$, respectively, and the values for the hind limb were $1.78 \%$, $87.14 \%$ and $11.03 \%$ (GÜNDEMIR et al., 2019). As in this study, it was seen that the CP and FF periods were longer in the forelimbs, and the PP periods were longer in the hind limbs. The statistical value of these differences was significant in two studies. It was concluded that $\mathrm{CP}$ time, including the part with the body pulling forward was longer in the forelimb compared to the hind limb. It was seen that the duration of PP including the part pushing the body forward, was long in the hind limb. With this method, these values provide information about lameness of the flexor and extensor muscles in the orthopedic field.

Clinical studies wereconducted previously regarding the stance phases in horses (BEHNKE, 2018; CLAYTON et al., 1998). It was only possible to examine the effects of the forces generated by muscles and tendons on the joints during trotting due to the insufficiency of the technology at the time those studies were performed, and the stance phases during walking were almost never investigated. As a result, no adequate data are available on the subject. Previous studies were mostly based on interpretations of the images recorded with highvelocity cameras using markers placed on horses in 
motion. In the present study, the OptoGait device was modified from human medicine, and enabled rapid objective results by processing the data obtained through infrared Led sensors using the accompanying software program. BEHNKE (2018) investigated the correlation between accelerationtime and the stance phases, and designed modeling associated with limb forces in horses. In another study, the activity of tendons during the stance phase was assessed (SWANSTROM et al., 2005).

In this study, the stages of the stance phases were also measured in $\mathrm{ms}$ alongside the duration of the stance phases, and the values obtained were compared with each other. Furthermore, the measurements were conducted on two different surfaces, and the results were comparatively evaluated to assertain the differences by using temporospatial gait parameters. Different systems have been used for gait analysis in horses. One of them is the Pressure Analysis System in which the force applied on the sole of the horse is measured and modeling executed (GOMES-COSTA et al., 2015). In this study, by performing center of pressure analysis using kinetic gait parameters, it was shown that horses show more postural stability than humans. According to the authors, studies evaluating temporospatial and kinetic gait parameters together will provide more objective results in the future.

Substantial advances have been achieved in recent years in veterinary medical studies concerning gait analysis, in parallel to the accelerating technological developments used in human medical research. Physicians have long benefitted from the novel devices developed and the increasing use of these systems in research, and hence from the more accurate data generated as practical auxiliary diagnostic tools in the clinical field. However, despite these technological innovations, "Machine versus Human" arguments lead to controversial issues in the medical field. At the same time, this phenomenon also raises controversy in equine medicine due to apprehension that new technology leads to "over diagnosing", as in the example of actual physiological and individual variations in animals being classified as lameness. This violates animal welfare and also causes significant financial loss in the equine industry. However, it should be noted that using the increasing quantity of physiological data obtained over time, as in the present study, will very probably prevent or at least minimize the possibility of over diagnosing.

In conclusion, the OptoGait analysis system is a feasible, non-invasive method (which eliminates the necessity of inserting markers or coils and etc. into the horse's body), appropriate for animal welfare, which is also considered to ensure the recognition of individual physiological variations in animals in further studies to be carried out in horses. Similar studies should be carried out to determine the usefulness of the OptoGait analysis system in examination of clinical lameness by determining the resulting physiological values of horses involved in different forms of races, different disciplines and on different surfaces by using this system.

\section{Acknowledgment}

We would like to thank the gait analysis expert, Nergis Pehlivan, Full Balance crew and Gürman Horse Riding Center for their contributions in providing a trained team and the equipment.

\section{References}

BEHNKE, R. (2018): Numerical time-domain modelling of hoof-ground interaction during the stance phase. Equine Vet. J. 50, 519-524.

DOI: $10.1111 /$ evj.12782

CLAYTON, H. M., J. L. LANOVAZ, H. C. SCHAMHARDT, M. A. WILLEMEN, G. R. COLBORNE (1998): Net joint moments and powers in the equine forelimb during the stance phase of the trot. Equine Vet. J. 30, 384-389.

DOI: $10.1111 / j .2042-3306.1998 . t b 04505 . x$

DONNELL, J. R., D. D. FRISBIE, M. R. KING, L. R. GOODRICH, K. K. HAUSSLER (2015): Comparison of subjective lameness evaluation, force platforms and an inertial-sensor system to identify mild lameness in an equine osteoarthritis model. Vet. J. 206, 136-142.

DOI: $10.1016 / j . t v j 1.2015 .08 .004$

DUCA, A., P. BRAMANTI, A. MIGLIORATO, A. CENTOFANTI, S. PORTARO (2017): Hippotherapy improves gait and balance in Down Syndrome. Ital. J. Anat. Embryol. 122, 86.

DOI: $10.13128 /$ IJAE-21478

ENGELSON, M. A., R. BRUNS, C. J. NIGHTINGALE, K. M. BARDWELL, C. A. MASON, S. TU, S. A. BUTTERFIELD (2017): Validation of the OptoGait system for monitoring treatment and recovery of post-concussion athletes. J. Chiropr. Med. 16, 163-169.

DOI: 10.1016/j.jcm.2016.12.001 
GOMES-COSTA, M., I. ROUPA, M. PEQUITO, J. PRAZERES, M. GAIVÃO, J. ABRANTES, H. M. CLAYTON (2015): The use of pressure plates for static Center of Pressure Analysis in horses. J. Equine Vet. Sci. 35, 315-320.

DOI: $10.1016 /$ j.jevs.2015.02.002

GÜNDEMIR, O., D. O. ERDİKMEN, Z. D. ATEŞPARE, K. AVANUS (2019): Examining stance phases with the help of infrared optical sensors in horses. Turk J. Vet. Anim. Sci. 43, 636-641.

DOI: $10.3906 /$ vet-1902-43

HEALY, A., K., LINYARD-TOUGH, N. CHOCKALINGAM (2019). Agreement Between the Spatiotemporal Gait Parameters of Healthy Adults from the OptoGait System and a Traditional Three-Dimensional Motion Capture System. J. Biomech. Eng. 141, 014501.

DOI: $10.1115 / 1.4041619$

KORSGAARD, E. (1982): Muscle function in the forelimb of the horse. An electromyographical and kinesiological study. PhD Thesis, Copenhagen, Denmark.

LEE, M. M., C. H. SONG, K. J. LEE, S. W. JUNG, D. C. SHIN, S. H. SHIN. (2014a): Concurrent validity and testretest reliability of the OPTOGait photoelectric cell system for the assessment of spatio-temporal parameters of the gait of young adults. J. Phys. Ther. Sci. 26, 81-85.

DOI: $10.1589 /$ jpts.26.81

LEE, M., C. SONG, K. LEE, D. SHIN, S. SHIN. (2014b): Agreement between the spatio-temporal gait parameters from treadmill-based photoelectric cell and the instrumented treadmill system in healthy young adults and stroke patients. Med. Sci. Monit. 20, 1210.

DOI: 10.12659/MSM.890658
LIENHARD, K., D. SCHNEIDER, N. A. MAFFIULETTI. (2013): Validity of the Optogait photoelectric system for the assessment of spatiotemporal gait parameters. Med. Eng. Phys. 35, 500-504.

DOI: 10.1016/j.medengphy.2012.06.015

MCLAUGHLIN, J. R., E. M. GAUGHAN, J. K. ROUSH, C. L. SKAGGS. (1996): Effects of subject velocity on ground reaction force measurements and stance times in clinically normal horses at the walk and trot. Am. J. Vet. Res. 57, 7-11.

MOORMAN, V. J., D. D. FRISBIE, C. E. KAWCAK, C. W. MCILWRAITH. (2017): The effect of horse velocity on the output of an inertial sensor system. J. Equine. Vet. Sci. 58, 34-39.

DOI: 10.1016/j.jevs.2017.08.009

PISTACCHI, M., M. GIOULIS, F. SANSON, E. DE GIOVANNINI, G. FILIPPI, F. ROSSETTO, S. Z. MARSALA. (2017): Gait analysis and clinical correlations in early Parkinson's disease. Funct. Neurol. 32, 28. DOI: $10.11138 /$ FNeur/2017.32.1.028

SWANSTROM, M. D., L. ZARUCCO, M. HUBBARD, S. M. STOVER, D. A. HAWKINS. (2005): Musculoskeletal modeling and dynamic simulation of the thoroughbred equine forelimb during stance phase of the gallop. J. Biomech. Eng. 127, 318-328.

DOI: $10.1115 / 1.1865196$

WEISHAUPT, M. A., T. WIESTNER, H. P. HOGG, P. JORDAN, J. A. AUER. (2004): Compensatory load redistribution of horses with induced weightbearing hindlimb lameness trotting on a treadmill. Equine Vet. J. 36, 727-733.

DOI: $10.2746 / 0425164044848244$

Received: 23 December 2019

Accepted: 8 September 2020

GÜNDEMIR, O., D. OLĞUN ERDIKMEN, Ç. PARKAN YARAMIŞ: Procjena stavova nogu i faza koraka pri hodu toplokrvnih sportskih konja na mekim i tvrdim površinama uporabom infracrvenih optičkih senzora. Vet. arhiv 91, 109-116, 2021.

\section{SAŽETAK}

Cilj rada bio je ustanoviti razlike u hodu sportskih konja na mekim i tvrdim podlogama, analizirajući faze koraka pomoću infracrvenih optičkih senzora. U istraživanje je uključeno 15 toplokrvnih sportskih konja. Analizirane su faze inicijalnog kontakta, kopita na zemlji i odskoka, uz procjenu tempa kretanja i dužine koraka. Uočeno je da su konji skloniji mnogo sporijem kretanju na mekanim nego na tvrdim površinama. Vrijeme provedeno na tabanima činilo je veći dio faze koraka na obje površine. Dužina odskoka bila je kraća na mekanim površinama u usporedbi s tvrdima. Omjer dužine kontakta prednjih udova bio je niži na mekanim površinama u usporedbi s tvrdima, a kod stražnjih udova omjer je bio veći na tvrdim površinama. Podaci dobiveni ovakvom analizom hoda mogli bi poslužiti kao dodatan dijagnostički alat u veterinarskoj medicine konja, posebice u bolestima lokomotornog sustava koje se očituju šepanjem. U budućnosti, odgovarajući bi sustavi primjenom postojeće tehnologije mogli ponuditi brze rezultate te osigurati ispravne rane zaključke u procjeni potencijala konja glede koraka, kasa i galopa.

Ključne riječi: analiza hoda; infracrveni optički senzori; faze koraka; konj 